\title{
STRATEGY FOR THE DEVELOPMENT OF SOCIAL INTERACTION BETWEEN ARCHITECTURE AND SOCIETY IN ENVIRONMENTAL PROGRAMS
}

\author{
IRINA TOPCHIY \& ALINA FATKULLINA \\ Moscow Architectural Institute (State Academy), Russia
}

\begin{abstract}
In modern theoretical and practical urban planning, the idea that the creation of conditions for the sustainable development of the human-made environment is solved by combining efforts of various social groups has taken root. The groups include city development planners, professional architects, urban planners and members of administrations and city residents. Architects believe that creation of public programs of additional architectural education devoted to sustainable development (energy conservation, landscaping, separate waste collection, etc.) is an effective way to popularize environmental initiatives. But do these subjects generate interest among members of the public of such a multinational megalopolis as Moscow? To answer this question, we carried out a sociological survey with participation of schoolchildren, students of the Moscow Institute of Architecture and the Moscow Civil Engineering Institute, teachers of the Moscow Architectural Institute and older residents of Moscow - participants of the Moscow Longevity Project. The survey results showed that the population of Moscow is nearly unaware of large-scale international and national environmental projects - the UN Sustainable Development Goals and the Environmental Doctrine of the Russian Federation. At the same time, respondents are well informed about the existing environmental problems; they believe that it is the city administration that is responsible for them and are taking part in resolving the challenge. The main conclusion: when developing a strategy for public architectural education, one should use pedagogical methods and techniques that increase the degree of community commitment of participants, allowing for their age-related interests and financial incentives.
\end{abstract}

Keywords: additional architectural education, continuing education, sustainable development, sustainable development goals, environmental doctrine.

\section{INTRODUCTION}

The exponential growth in the number of scientific studies devoted to rational use, conservation of natural resources and the sustainable development of the human-made environment coincided with the beginning of the globalization period in the late 1980s. It became one of the global challenges the international community faced. In the succeeding decade, environmental programs were introduced into vocational education in most technical, humanities, and social sciences. An environmental education strategy was defined by Tilbury and Wortman [1], Eckersley [2], Huckle and Sterling [3] and Rieckmann [4]. Various stages of students' perception of environmental threats were found (Hicks and Holden [5]). This resulted in a sense of empowerment of students. Hence, it was proved that all types of environmental education for the development of society in total is valuable.

Principal foreign universities and research centers that host interdisciplinary scientific conferences and engage new researchers in scientific work (Wessex Institute, UK; The University of Exeter, Cornwall, UK; Harvard University, USA; Japanese Center for International Studies in Ecology (IGES-JISE), Japan, etc.), currently support environmental and sustainable development topics. The European Commission (Eurobarometer, EC website) regularly monitors the degree of environmental awareness of European Union residents and other countries of the world. The number of citizens who consider themselves 
well-informed on environmental issues in 2017 exceeded 97\%. Previous environmental awareness indicators ranged from $78 \%$ in Denmark to $30 \%$ in Romania [6]. The percentage of people who think that environmental protection is important for them personally ranges from country to country - from $87 \%$ in Sweden to $40 \%$ in Cyprus and Croatia. There is a striking opinion discrepancy concerning which environmental problems should be tackled first. As most important respondents consider the problems of climate change (up to 51\%), air pollution (46\%), and increasing waste generation (40\%).

Majority of environmental problems are caused by urbanization and, logically, fall within an area of interest of architects, urban planners, scientists and teachers of vocational schools.

Textbooks entered the practice of Russian-language architectural and urban planning vocational education in the 1990s. They covered the planning, organizational and technical aspects of ecology and sustainable urban development [7], [8]. At present, the pedagogical studies of environmental education in our country and abroad are focused on formal types of education for schoolchildren and science and engineering students, forming a continuing education system. Methods and models for the organization of the human-made environment that take into account the sustainable development and uniqueness of urban ecosystems, the ecology of soils, forests, water and air, were proposed. The results of their research were introduced into the curricula of professional architecture education and were targeted at professional improvement of architects of all specialties. Long-term practice of environmental general and vocational education has contributed to a spread of environmental awareness among highly socially active and educated people.

How broad is the range of sustainability professionals in the Russian Federation and were they able to spread their knowledge among other members of society and pass it on to other generations? This aspect has not yet been studied.

\section{RESEARCH METHODOLOGY}

\subsection{Purpose and objectives of research}

The purpose of this research was to develop a strategy for the development of public architectural education in the field of ecology.

The objectives include:

- identification of aspects of modern environmental programs affecting various social groups of the city;

- written questionnaire survey of participants of Moscow projects "University Saturdays" and "Moscow longevity" to find their awareness of environmental projects and the extent of involvement;

- evaluation of the extent of awareness of environmental programs in different social groups of the Moscow population (children, their parents, students, older people) and, in case of deficient knowledge, introducing the information to the curricula of basic and additional architectural education at the Moscow Architectural Institute;

- development of measures to improve the knowledge and understanding of Moscow environmental programs.

\subsection{Methods of research}

A sociological study was carried out in September-November 2019 in the form of a survey. When developing the questionnaires, the UN Sustainable Development Goals (2015-2030), 
the Environmental Doctrines of the Russian Federation and the current state city programs of Moscow were used.

The reliability of the information collected was determined by the qualitative and quantitative selection of respondents - focus groups representing different age and professional categories of Muscovites and by a short survey period (September-November 2019). When selecting focus groups, the feasibility of application of the obtained data in professional and additional architectural education at the Moscow Architectural Institute (MARCHI) and Moscow State University of Civil Engineering (MGSU) was taken into account. Four focus groups were identified: students of architectural faculties; students of pre-entry courses - future applicants of architectural faculties; adults of different professions - parents of applicants; participants in the Moscow Longevity Project (women over 55 and men over 60 ). The survey was conducted either in openness or anonymity.

Two categories of respondents participated in the survey: One category consists of those professionally involved in architecture and urban planning and the other includes city residents who evaluate and use the planning results, (the second category includes residents who participate in architecture and urban planning activities, but whose involvement in architecture and urban planning is not professional [9]). The groups do not differ much in number of respondents: the first group consists of 65 people and the second group consists of 113 people.

\section{THE CONTENT AND RESULTS OF THE RESEARCH}

The content of the research and its results are presented in Tables 1-5. Each table features a questionnaire and shows the percentage of respondents' answers as a percentage of the total. The statistics allow the comparison of the opinions of two categories of respondents students of architectural schools MARCHI and MGSU (professional participants in architectural and urban planning) and other social groups (non-professional participants in architecture and urban planning).

Table 1: Question 1. Awareness of the surveyed of international and national environmental projects.

\begin{tabular}{|c|c|c|c|}
\hline & & $\begin{array}{l}\text { Professional participants } \\
\text { in architecture and urban } \\
\text { planning (students of } \\
\text { architectural schools } \\
\text { MARCHI and MGSU) } \\
\text { (\% of the total) }\end{array}$ & $\begin{array}{l}\text { Non-professional } \\
\text { participants in architecture } \\
\text { and urban planning } \\
\text { (schoolchildren and their } \\
\text { parents, pensioners) } \\
\text { (\% of the total) }\end{array}$ \\
\hline \multirow{2}{*}{$\begin{array}{l}\text { Are you familiar with } \\
\text { the UN Sustainable } \\
\text { Development Goals } \\
\text { concept? }\end{array}$} & Yes & 11 & 0 \\
\hline & No & 89 & 100 \\
\hline \multirow{2}{*}{$\begin{array}{l}\text { Are you familiar with } \\
\text { the environmental } \\
\text { doctrine of the Russian } \\
\text { Federation? }\end{array}$} & Yes & 3 & 0 \\
\hline & No & 97 & 100 \\
\hline
\end{tabular}


Table 2: Question 2. Level of awareness of the surveyed of the environmental problems of Moscow.

\begin{tabular}{|l|c|c|}
\hline \multirow{2}{*}{$\begin{array}{l}\text { Problems of ecology and } \\
\text { sustainable development }\end{array}$} & $\begin{array}{c}\text { Professional participants } \\
\text { in architecture and urban } \\
\text { planning (students of } \\
\text { architectural schools } \\
\text { MARCHI and MGSU) }\end{array}$ & $\begin{array}{c}\text { Non-professional } \\
\text { participants in architecture } \\
\text { and urban planning } \\
\text { (schoolchildren and their } \\
\text { parents, pensioners) }\end{array}$ \\
\cline { 2 - 3 } & \multicolumn{2}{|c|}{ Mid-rank at ranking } \\
\hline $\begin{array}{l}\text { Air, water and soil pollution } \\
\text { by transport and industrial } \\
\text { enterprises }\end{array}$ & 1.6 & 1.1 \\
\hline $\begin{array}{l}\text { Noise and visual pollution of } \\
\text { Moscow }\end{array}$ & 2.4 & 2.13 \\
\hline $\begin{array}{l}\text { Preservation and protection of } \\
\text { Moscow historical and } \\
\text { cultural heritage }\end{array}$ & 2.96 & 2.4 \\
\hline $\begin{array}{l}\text { Social conflicts in a } \\
\text { multiethnic city }\end{array}$ & 3.31 & 2.4 \\
\hline $\begin{array}{l}\text { Financial stability of Moscow } \\
\text { residents }\end{array}$ & 3.33 & 2.4 \\
\hline $\begin{array}{l}\text { Organization of domestic and } \\
\text { international tourism in } \\
\text { Moscow }\end{array}$ & 4.44 & 2 \\
\hline
\end{tabular}

Table 3: Question 3. Responsibility of residents for solving environmental problems of the city.

\begin{tabular}{|l|c|c|}
\hline Factors & $\begin{array}{c}\text { Professional participants } \\
\text { in architecture and urban } \\
\text { planning (students of } \\
\text { architectural schools } \\
\text { MARCHI and MGSU) } \\
\text { (\% of the total) }\end{array}$ & $\begin{array}{c}\text { Non-professional } \\
\text { participants in architecture } \\
\text { and urban planning } \\
\text { (schoolchildren and their } \\
\text { parents, pensioners) } \\
\text { (\% of the total) }\end{array}$ \\
\hline $\begin{array}{l}\text { Decisions of the mayor and } \\
\text { other members of the city } \\
\text { administration }\end{array}$ & 37 & 100 \\
\hline $\begin{array}{l}\text { Urban development projects } \\
\text { and decisions of the chief } \\
\text { architect }\end{array}$ & 38 & 67 \\
\hline $\begin{array}{l}\text { Willingness and support of } \\
\text { residents }\end{array}$ & 38 & 50 \\
\hline $\begin{array}{l}\text { New technologies (which } \\
\text { one) }\end{array}$ & 7 & 34 \\
\hline
\end{tabular}


Table 4: Question 4. Participation of Moscow residents in environmental projects and movements.

\begin{tabular}{|l|c|c|}
\hline $\begin{array}{l}\text { Environmental projects and } \\
\text { movements }\end{array}$ & $\begin{array}{c}\text { Professional participants } \\
\text { in architecture and urban } \\
\text { planning (students of } \\
\text { architectural schools } \\
\text { MARCHI and MGSU) } \\
\text { (\% of the total answers) }\end{array}$ & $\begin{array}{c}\text { Non-professional } \\
\text { participants in architecture } \\
\text { and urban planning } \\
\text { (schoolchildren and their } \\
\text { parents, pensioners) } \\
\text { (\% of the total answers) }\end{array}$ \\
\hline $\begin{array}{l}\text { I stopped using individual } \\
\text { transport, I use public } \\
\text { transportation and walk }\end{array}$ & 52 & 66 \\
\hline $\begin{array}{l}\text { I sort household waste (paper, } \\
\text { plastic, glass, metal) and } \\
\text { bring it to recycling centers }\end{array}$ & 40 & 75 \\
\hline $\begin{array}{l}\text { I care for greenery at building } \\
\text { (or school) surrounding } \\
\text { grounds }\end{array}$ & 19 & 50 \\
\hline $\begin{array}{l}\text { I save electricity, turn off } \\
\text { unnecessary electrical } \\
\text { appliances }\end{array}$ & 81 & 100 \\
\hline Other & 3 & 8 \\
\hline
\end{tabular}

Table 5: Question 5. Limitations and rejection of environmental initiatives.

\begin{tabular}{|l|c|c|}
\hline $\begin{array}{l}\text { Environmental projects and } \\
\text { movements }\end{array}$ & $\begin{array}{c}\text { Professional participants } \\
\text { in architecture and urban } \\
\text { planning (students of } \\
\text { architectural schools } \\
\text { MARCHI and MGSU) } \\
\text { (\% of the total answers) }\end{array}$ & $\begin{array}{c}\text { Non-professional } \\
\text { participants in architecture } \\
\text { and urban planning } \\
\text { (schoolchildren and their } \\
\text { parents, pensioners) } \\
\text { (\% of the total answers) }\end{array}$ \\
\hline Use of individual transport & 7 & 83 \\
\hline $\begin{array}{l}\text { Use of high-power appliances } \\
\text { (an iron, a heater, ...) }\end{array}$ & 81 & 50 \\
\hline Plastic bags in supermarkets & 11 & 16 \\
\hline Other & 3 & 0 \\
\hline
\end{tabular}

\section{CONCLUSIONS}

1. Representatives of all groups unanimously admitted that they are not familiar either with the Environmental Doctrine of the Russian Federation or with the UN Sustainable Development Goals. This fact indicates a lack of attention in organizing the promotion of environmental programs on the part of the mass and professional media, members of the administration, and teachers of architectural faculties. Obviously, at the moment social groups are not unanimous in the actions and this hampers implementation of environmental programs. Social advertising of environmental programs aimed at 
changing the existing behavioral model in relation to the environment could become one of the remedies.

2. Respondents believe that all problems of sustainable development of the urban environment listed in the questionnaire are equally important. Younger respondents rated the transport problem a little higher than others. This is due to a higher mobility of the young generation and is confirmed by psychological and pedagogical researches that demonstrate that the growing commuting activity happens during professional growth and decreases with age. Students and children are more interested in issues of organizing domestic and international tourism. At that all groups of respondents ranked the problem of ensuring the inflow of tourists as least important, despite the active media support of the federal target program "Development of domestic and inbound tourism in the Russian Federation" (2019-2025).

3. Respondents were unanimous in their opinion that the primary factor on which the sustainable development of the city depends is the activities of the Mayor of Moscow City and the city administration. The second in order of importance factor is "urban development projects and decisions of the chief architect", the significance of which students of architectural schools consider as principal. The importance of "willingness and support of residents" for sustainable development was noted by less than 5-7\% of the respondents of all social groups. The fewest number of respondents found a relationship between sustainability of the urban environment and introduction of new technologies significant. Muscovites who rest environmental responsibility on the city administration are not ready to be fully engaged in the city's environmental programs.

4. Answers to questions about participation in Environmental movements and Projects should be considered in strong dependence on the characteristics of social groups. The biggest number of positive responses $(50-80 \%)$ in the questionnaires filled in by children and older citizens refer to the "I stopped using individual transport" item. Because these social categories are low in mobility and seldom use individual transport, their refusal to use it does not contradict usual patterns as well as a refusal to use high-power electric appliances which is both environmentally and economically efficient.

5. The idea of not using plastic bags offered in supermarkets was least supported by all social groups, which is surprising, considering that the plans for a phased reduction in the production of plastic bags, was already legally agreed upon with the Ministry of Natural Resources and Ecology of the Russian Federation.

6. The survey of Muscovites confirmed the hypothesis of a very superficial attitude to the environmental problems of Moscow and a shift of environmental responsibility onto governance bodies. It is evident that this approach hampers the participation of residents in environmental programs.

Majority of Muscovites are aware of the environmental problems of the city and are practically engaged in their solution in compliance with their age and professional interests.

Muscovites are not ready to limit their consumption habits and sacrifice the customary level of comfort to alleviate harmful pressure on the environment.

\section{REFERENCES}

[1] Tilbury, D. \& Wortman, D., How is community education contributing to sustainability in practice? Applied Environmental Education and Communication, 7(3), pp. 83-93, 2008.

[2] Eckersley, R., The death of nature and the birth of the ecological humanities. Organisation and Environment, 11(2), pp. 183-185, 1998. 
https://research.monash.edu/en/publications/the-death-of-nature-and-the-birth-of-theecological-humanities. Accessed on: 19 Jan. 2019.

[3] Huckle, J. \& Sterling, S., Education for Sustainability, Earthscan: London, 1996.

[4] Rieckmann, M., Higher education for sustainable development in Germany: Achievements, good practice and next practices. Conference Education for Sustainability in Higher Education - Achievements. and Prospects, Plymouth University, 8th Jan. 2015.

www.academia.edu/10077522/Higher_Education_for_Sustainable_Development in Germany_Achievements_Good_Practice_and_Next_Practices. Accessed on: 21 Jan. 2020.

[5] Hicks, D. \& Holden, C., Remembering the future: What do children think? Exploring the Future: A missing dimension in environmental education. Environmental Education Research, 30 Jan. 2009, pp. 1-10.

https://ore.exeter.ac.uk/repository/bitstream/handle/10036/48250/Remembering\%20t he\%20future.pdf?sequence=2. Accessed on: 21 Jan. 2020.

[6] Punzo, G., Panarello, D., Pagliuca, M. \& Castellano, R., Evaluating the attitudes of Europeans towards the environment. Statistical Methods for Service Quality Evaluation, eds M. Bini, P. Amenta, A. D'Ambra \& I. Camminatiello, Cuzzolin: Naples, pp. 336-339, 2019.

[7] Chernova, N.M. (ed.), Ecology. Textbook for 10-11 forms. 11th ed., 2007.

[8] Ecology, 7th ed., Academia, 2019, p. 203.

[9] Topchiy, I., Subjects of architectural urban activity. Journal of Urbanism, Architecture and Design, pp. 16-19, 2016. (In Serbian.) 